\title{
High standards urged for French charities
}

Paris. French researchers were warned last week to observe the highest standards of openness and scientific integrity in their dealings with research charities, and to ensure that such charities are run with exemplary levels of transparency and quality.

The warning was issued in a report by an ethics committee of the National Centre for Scientific Research (CNRS), set up in 1994 to identify ethical problems in research. The 14 members of the committee, known as COMETS, are drawn from academic institutions, the legal profession and other sectors. They include the former science minister and CNRS director Hubert Curien, and the panel is chaired by Hélène Ahrweiler, a former rector of the Academy of Paris.

The committee's report was prompted by a recent financial scandal at France's largest medical charity, LAssociation pour la Recherche contre la Cancer (ARC) (see Nature 379, 103; 1996). Its 14 recommendations, proposed as a code of conduct for researchers working with charities, represent a belated attempt to close some of the glaring gaps in the regulation of French charities that were exposed by the ARC scandal. "No cause, however sacred, authorizes the sacrifice of moral values," says the report, an implicit criticism of the fact that many scientists associated with ARC had long turned a blind eye to activities at the charity, even defending it against allegations of mismanagement and wrongdoing.

The ethics committee recommends that scientists who sit on the boards of charities should avoid acting as both "judge and jury", and that funds should be distributed by independent scientific committees. (The executive board of ARC included many members who received large amounts of funding from the charity.)

Members of such committees should ensure that charities distribute grants fairly, and evaluate how money is spent. If researchers suspect wrongdoing, they should "not hesitate" to withdraw their support for a charity and to "make public their disagreement", says the report, in an explicit call for more whistleblowing

Researchers themselves should submit funding received from charities to the rigor- ous accounting procedures used by the research organizations to administer their budgets, it adds. This is already a legal obligation. But many researchers have operated separate accounts to administer funds they receive from charities; an audit of ARC found that many recipients of the charity's grants were unable to provide receipts to confirm how they had spent the money.

The report also warns researchers against colluding with aspects of fundraising that could mislead the public and so damage the image of research. Scientists should be careful not to raise unduly the public's hopes of medical progress; they should rather explain the long-term nature of research and the need to support fundamental research.

The thrust of the report is that, although funding of research by charities is increasingly important in France, it is only a fraction of the total state investment in science. Researchers need to avoid becoming dependent on outside associations, and should ensure that they do not unduly influence the direction of their research or policies, says the report. Declan Butler

\section{Sceptics course seeks to stem 'tide of irrationalism'}

Boston. Eager to train the next generation of qualified sceptics, the Center for Inquiry Institute - a branch of the Committee for the Scientific Investigation of Claims of the Paranormal (CSICOP) - has launched a three-year academic programme leading to a certificate of proficiency in "science and the paranormal" and "humanistic studies".

The aim is to boost the ranks of those prepared to challenge what some describe as a "rising tide of irrationalism", with 48 per cent of Americans believing in unidentified flying objects, according to a recent poll, and 29 per cent convinced that contact has been made with aliens.

The academic programme was announced last month at the First World Skeptics Congress, held at the State University of New York at Buffalo, in celebration of CSICOP's twentieth anniversary. A Council for Media Integrity on Science, aimed at countering distorted views of science presented in the media, is also being set up.

The Center for Inquiry Institute has been running workshops, seminars and conferences since it was formed in 1987. But Paul Kurtz, the chairman of CSICOP, says that the more formal programme will be the "first effort to develop the tools of sceptical thinking in a systematic way and to apply it to a wide range of questions".

To complete the programme, students will need to acquire 30 credits through courses, workshops and a research paper or thesis. "How fast people can graduate depends on how fast we can offer courses," explains Joe Nickell, associate dean and a senior research fellow at CSICOP.

The centre is exploring the possibility of gaining accreditation for the programme, and is an accredited research institute of Westminster College, associated with the University of Oxford, Nickell says. "My feeling is that not many sceptics are planning to take our courses for college credit, as so many of them are beyond college."

Eugenie Scott, a physical anthropologist and executive director of the National Center for Science Education in Berkeley, California, thinks the programme will be worthwhile, regardless of credits or accreditation. "Studying paranormal claims is a good way to learn critical thinking and to learn about the scientific method - the need for empirical evidence, experimental

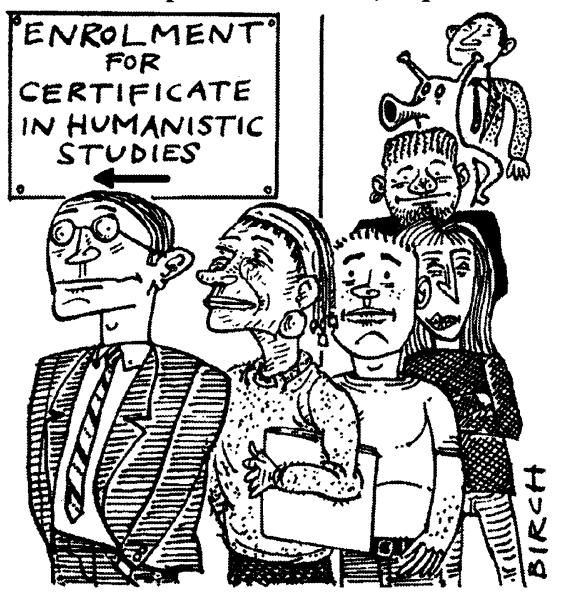

controls and so forth," she says. "Studies have shown that individuals who understand science live in a less fearful world."

But some sceptics are themselves somewhat sceptical of the initiative. Ray Hyman, for example, a psychologist at the University of Oregon, and a well-known debunker of extra-sensory perception and other paranormal phenomena, says it unlikely that his successor will emerge from the programme.

"You need a lot of training in statistics and laboratory work to do what $I$ do, and you're not going to get that by taking a few courses," he says. "While I have my doubts as to why people need formal certificates, I do think that sceptics need training." One problem is that "there are no ground rules or manuals on how to be a good sceptic". Hyman believes that critical thinking can be taught. But it is even more important to learn how to get good information.

Communication skills are crucial in this field, Hyman maintains, and courses on the subject are being offered by the centre. "We've had more trouble with people who claim to be sceptics talking out of turn, speaking without knowing what they're talking about, than we've had with paranormal believers," he says.

Manners are important too, he stresses. "The trick is how to tell people they're wrong without putting them down. Sceptics have to be civilized in their delivery, because we won't reach the 'believers' by attacking them and making them more defensive."

Steve Nadis 